\title{
Academic precarity as hierarchical dependence in the Max Planck Society
}

\author{
Vita Peacock, University College London
}

This essay examines the idiosyncratic internal hierarchy of Germany's foremost research organization, the Max Planck Society. It employs Louis Dumont's analytics of paramount value, encompassment, and complementarity to convey the symbolic logic of relations therein. One consequence of this is to show that the organization's paramount values of autonomy and excellence (embodied by its governing community of directors who encompass their departments) produce the complementary value of dependence for subalterns. Ethnographic engagement with three post-PhD scientists demonstrates that dependence is thereby constituted as a "mode of action" in James Ferguson's terms, which hinges on their director's support. The essay concludes that the ubiquity of temporary contracts among these actors does not arise simply-as many presume-from a generic neoliberal precariatization of the academy. Instead, precarity of employment in the Max Planck Society is the contemporary expression of dependencies initiated by a far older tradition of intellectual leadership, and the morphologies of German monarchy that preceded it.

Keywords: hierarchy, dependency, personhood, precarity, Germany, kingship

In the last three decades precarity and its cognates, precarious and precariousness, have been advancing as categories to describe a new regime of labor. The process began sometime in the mid-1980s, when labor economists and political scientists began to attend to a seismic shift unfolding in their data. They were confronted with more and more evidence of deviation from the so-called "standard employment relationship"-meaning "full-time, regular and permanent employment" (Deakin 1986: 225) — that had characterized the postwar settlement. On the back of the 1970s employment crisis and a general slowing of employment growth through the 1980s, a new "atypical" or "nonstandard" employment relationship was 
appearing with greater frequency (Rodgers and Rodgers 1989): temporary or contract work, home-working, self-employment, part-time work and irregular work in the black economy (Ruberry 1989). At the same time, national governments were systematically loosening previously standardized and collectivized labor controls, rendering this once "atypical" employment increasingly typical-as part of a process now called neoliberalism (Harvey 2005). The expansion of precarious forms of work-which by the 1990s had come to signify all that was somehow temporary (Bosworth 1991; European Foundation 1997; Vosko 2000)—was thus conceived as one of the primary consequences of this new politico-economic order.

More recently, there has been a charged discussion around the effects of this order on academic institutions. These have been broadly conceived as attacks on disciplinary integrity (Dyck 2014; Mitchell and Dyck 2014; Kapferer 2005); the dramatic expansion of audit (Strathern 2000) and its attendant ranking practices (Groat 2015); and attempts to substitute academic for nonacademic values, particularly economic (Hall and Sanders 2015; Garland 2008; Knowles and Burrows 2014; Mitchell 2014). In tandem with these, an ideological logic of "responsibilization" (Butler and Athanasiou 2013)—which legitimates the transference of structures of social and economic risk from governments and institutions onto individuals (Beck 1992) - has been widely regarded as the culprit for the normalization of precarious employment within the academy (Giroux 2014; Maroudas and Nikolaidis 2013; Teeuwen and Hantke 2007).

As such, the neoliberal enterprise and its effects felt apposite to my initial encounter with the post-PhD scientists of the Max Planck Society (alternatively the Society or MPS). ${ }^{1}$ The MPS is a large-scale nonprofit research organization spread over eighty-three Institutes across Germany with five abroad; and one of its most particular anthropological features is the profoundly polarized temporal experience of its workforce. The large majority of scientists below the director stratum are employed on temporary contracts; meanwhile the large majority of its technical staff and administrative staff, along with the directors of the Institutes, are employed there permanently. The Society's post-PhD staff thus offered an excellent example of precarious living. As a consequence, I excitedly drew up several graphs on how the organization's contractual commitments to its employees had declined since the early 1990s. ${ }^{2}$ I also listened with great interest to the scientists'

1. I spent a total of fifteen months from 2010 to 2012 at various MPS sites across Germany. These included four distinct Institutes (in Berlin Brandenburg and North Rhine-Westphalia), the bureaucratic headquarters in Munich, and the Society's Castle in Alpine Bavaria. It is important to be clear from the outset-particularly for the benefit of my disciplinary colleagues working inside the organization-that all of these Institutes were engaged in natural scientific research. The empirical basis of this study, and therefore this argument, is one that extends only to the natural scientific relations of knowledge production in the MPS. Nevertheless, over the years since beginning this project, I have heard many similar tales of individualized dependence relations in German institutions beyond this sphere, and I would not wish the limits of my claims to obstruct a broader resonance elsewhere.

2. I compiled two graphs on the contractual nature of scientific employment from 1974 to 1994 and from 2002 to 2011, based on quantitative data gleaned from the MPS's 
descriptions of their lives and attitudes, which seemed to bear all the hallmarks of precarious subjectivity: a preferential focus on the present, an ability to manage high levels of "stranger sociality" (Povinelli 2006), and even a love of extreme sports like air-gliding, rock-climbing, and snowboarding (Baker and Simon 2002). It seemed sufficient to theorize the experiences of the MPS's scientific staff as those of just another precarious group, whose employment situation had brought with it a characteristic "way of life" (Berlant 2011: 192). It took me some time to realize that to do this was to neglect the organization as a cultural space: i.e., one where historic convictions about what relationships should be overdetermine those that end up developing.

In an apparent paradox, the very etymology of precarity provides the key to unlock this space. Precarity is a dead metaphor of landholding. Its cognate "precarious" first appeared in the English language in 1646 as a legal term to signify a particular form of contract between landlord and tenant. From the Latin precārius meaning "obtained by prayer" (Skeat 1910: 470), a precarious tenancy was one in which land was held "at the will of" or "at the pleasure of" the landholder (OED 2014) - with no promise of security nor permanence beyond that assured by such will or pleasure. To my knowledge it is only Lauren Berlant who has made the connection between precarity's heritage and its present-day form. She tantalizes the reader with an almost throwaway remark that precarity is "at root, a condition of dependency" (2011: 192, emphasis added) before soaring off into the theoretical constellations of a "neoliberal feedback loop" (2011: 193). Instead of joining Berlant on this cosmic leap I'd like to keep the argument chthonic. I want to hold onto the insight that precarity is a condition of dependence because it is this that enables us to make that E. P. Thompson-esque knights-move (1963), reframing a sociological category as anthropological: that is, as a social relation. ${ }^{3}$ If a precarious existence is one side of a reciprocal dynamic in which one lives at the will or pleasure of another person, then the first question that follows is-precisely who is this person?

In the Max Planck Society, the vast majority of post-PhD scientists are employed to work within a specific department that is governed by an appointed director (who is also a scientist). ${ }^{4}$ This director is responsible for all hiring decisions as well as the overall direction of research the department pursues, pouring his or her funding streams this way or that. Although they have their own projects, these

Annual Reports (Jahresberichte) housed in the Max Planck Archive. These statistics make two things abundantly clear: i) that the total population of the organization has increased by a multiple during this 37 -year period, and ii) this explosion has made the differing proportions of those on permanent and temporary contracts far more pronounced.

3. One reviewer proposed the relevance of Pierre Bourdieu's Homo Academicus (1988) to this argument. While it is indeed relevant, this is perhaps not in the way that was presumed. Bourdieu's project has a wholly inverse relation to the one I am pursuing here: animating, as he does, the economic language of capital in the analysis of academic personhood.

4. This description does not include those employed within the Max Planck Research Groups: small teams of researchers who work independently from any director but are usually restricted to a maximum life cycle of five years. 
scientists work, in the final analysis, "at the pleasure of" the director because these must be successfully subsumed within the latter's broad vision. ${ }^{5,6}$

The directorship is an unusually pronounced concept of leadership, with morphological roots in the governance of hundreds of principalities of the Holy Roman Empire (Vierhaus 1988). In the wake of the French Revolution, the self-designated "German Idealists" (notably Fichte, Herder, and Humboldt) effectively asserted for German intellectuals the societal significance once the property of these ruling princes-positioning learned men as Kulturträger (culture-bearers) of a new integrated German nation (Boyer 2005: 57). Turn now to 1911 when the Max Planck Society's predecessor, the Kaiser Wilhelm Society, is founded, and it is this particular admixture of leadership that becomes the defining social fact of the new institution. When the 1980s brings with it a broad trend for those in weaker occupational locations to be stripped of permanent positions, this begins to directly affect those beneath the director stratum when the organization undergoes seismic change after the reunification of Germany in 1990. However, the decline in wissenschaftliche Planstellen (permanent scientific posts) never reaches the directors-whose numbers have remained fairly constant and who have as much contractual security as they ever did. Casting back to the feudal history of precarity thus sheds its apparent paradox, because the insulation of the directors from these trends can only be explained through the persistence of a much older societal logic. ${ }^{7}$ For if the monarch is the source of "life" and of social "reproduction" (da Col and Graeber 2011: xxiii), then he (and now she) must be maintained in a position of total safety. And if the monarch is the source of life, $s($ he) is also the principal avenue for those around them to realize theirs.

\section{Precarity as dependence}

The question of dependence has recently been discussed in some depth by James Ferguson and seven commentators (Ferguson 2013; Bolt 2013; Bonilla 2013; Englund 2013; Haynes 2013; Li 2013; Shah 2013; White 2013). For Ferguson dependence is

5. There are two caveats. First, two institutes in North Rhine-Westphalia are half financed by German industry, diminishing the intellectual control of the directors therein. Second, there is one way around the material dependence of subalterns upon the director, which is in the securing of third-party funding. However, on the latter point the remarks about intellectual encompassment still apply.

6. To argue that post-PhD scientists exist in a relation of hierarchical dependence upon their directors is not to say that the latter possess no reciprocal obligations. Indeed the majority of directors I met exhibited a profound sense of responsibility for the career progression of those in their charge (see my discussion of hierarchy and responsibility in Peacock [2015]). Nonetheless, the directors are manifestly not dependent upon their staff for their positions within the organization (this rests with other scientific members), making the quality of these obligations rather different.

7. It also allows us to elude a political concern raised by Keir Martin (2014) that I also share: namely, to assume all forms of precarity are necessarily "neoliberal" is itself an intellectual capitulation to the ideology. 
an inherently hierarchical relation. This means that the primary plane of interaction is not between people- "abstract individuals" (Kapferer 2005: 8) acting in apparent freedom-but between persons-people inhabiting social roles conceived as functionally interdependent. Ferguson's clear intellectual adversary is the tradition of liberal thought that has pathologized (Fraser and Gordon 1994) dependence as a condition of shameful passivity. Instead, he argues, in southern Africa the opposite has historically been true. There, dependence is a cultural "mode of action" (2013: 237) that presents a means of realizing human potential rather than obliterating it.

Ferguson's most provocative and valuable contribution is the notion of "desirable" (2013: 237) dependence, a subject many of his interlocutors acknowledge has been woefully ignored. All accept the premise that dependence can be a mode of action-in Africa (Haynes 2013) as well as elsewhere in the Global South (Bonilla 2013) - and in rescuing dependence from the throes of liberal pathology Ferguson "recovers intellectual resources within the discipline" (Englund 2013: 248). These resources also enrich an understanding of the Max Planck Society. I am often told by scientists that "everything depends on the director" as a simple statement of cultural fact. ${ }^{8}$ Dependence is the way the MPS "works," and must be evenly and reflexively negotiated if it is to offer them a mode of action. On encountering desirable dependence in this German organization, however, one underlying assumption these scholars share is contravened: namely, dependence is not a conception of relations that societies in Europe would ever approbate. ${ }^{9}$ When MPS scientists say that everything depends on the director without any evidence of a liberal "repugnance" (Mahmood 2005) they are showing this is not necessarily the case. A different model of personhood lives inside this German organization that is decidedly nonliberal. Part of the story of this essay is therefore how and why the Max Planck Society has been able to resist a particular strand of Western liberal thought, retaining dependence as potentially desirable.

In asserting that the Society is organized through a hierarchical relation I am also pursuing certain propositions of Louis Dumont: in particular his notions of paramount value, encompassment, and complementarity. ${ }^{10}$ Dumont's study of the arrangement of castes in India leads him to the structuralist conclusion that there

8. Such a statement is often asserted as reasoning for why an anthropology of the Max Planck Society would be impossible, all departments being too different to enable comparison. Of course, this very diversity proves the converse is true: each department constitutes one iteration of the shared cultural idiom of director-dependence.

9. Iteanu and Moya, in a recent appraisal of Dumont's comparative project, also take the same position: that across this cultural space all hierarchical relations are construed as domination (2015: 118).

10. Although hierarchy—whether "formal" or "informal" (Diefenbach and Sillince 2011) — is often acknowledged as a facet of organizational life, this is the first application of Dumont's thought to the ethnography of an organization. This may be at least partly due to the latter's profound influence by postmodern and poststructuralist theory, which asserts the primacy of action and the interminable production of social life (Born 1995; Kunda 1992; Latour 2010; Law 1994; Zaloom 2006). The analysis of value inside organizations has thus in recent decades been very marginal (although see Kondo [1990] and Garsten [1994]). 
is a single "paramount value" that shapes the entire system: religious purity. ${ }^{11}$ Purity for Dumont is like an "immense umbrella sheltering all sorts of things which we distinguish" (1980: 60), and one of its clearest social consequences is the hierarchical preeminence of Brahmans, conceived as the purest group. ${ }^{12}$ As his image suggests, however, rather than a linear hierarchy of degrees of relative purity, Dumont's conception of Indian society is taxonomic, operating through "a series of successive ... inclusions" (1980: 67). Purity is consequently not separate from its opposite but instead encompasses it within itself. In fact, he maintains, without impurity there could be no purity; the two are "conceptually inseparable" (1980: 54). It is the functional interdependence of these opposites that Dumont calls complementarity. Purity's encompassment of its contrary is, in fact, the only way it can realize itself as a paramount value.

Hierarchy in this German setting arises, of course, from a very different set of conditions to the Indian case, thus Dumontian thought must be adapted to its nuances. In fact, there is really one clear distinction on which all others turn, which is in the embodiment of paramount values. For Dumont this is unmistakably a group - the Brahmans-yet in the MPS these values are embodied by individualsthe directors. However, Joel Robbins points out Dumont's acknowledgement that the individual as a carrier of value always rested on a fallacy-that one can ever be fully separate from society. Robbins's conclusion is that "individualism must always be found in some combination with holism" (2015: 174), and this is unmistakably what we find in the MPS: where this combination is one of encompassment. Each individual director stands thus encompasses the whole of their departmental community. Dumont himself gets halfway there, by calling German ideology some combination of "community holism and self-cultivating individualism" (1994: 20), in a work that André Iteanu and Ismaël Moya suggest shows Dumont's ability to accept flaws in his earlier reasoning (2015: 116). I find this perhaps too forgiving. The text remains torn with ambivalences, Dumont quite unable to see how individualism and holism could coherently work together. ${ }^{13}$ Presenting the Max Planck Society as a hierarchical system in which individualism not only operates alongside but also actually encompasses holism within itself is subsequently to take Dumont's thought to a logical conclusion that he was never able to.

This brings us full circle to the theoretical submission of precarity as a form of dependence. If paramount value in the MPS is attached most fully to its directorswho incarnate the values of autonomy and excellence-then complementarity implies that the group they encompass as individuals must be dependent. Indeed, just as with Dumont's purity, the autonomy of the directors can only be realized as a

11. Dumont sometimes uses different language to describe the same phenomenon. Elsewhere this is also referred to as the "preeminent value-idea" (1986: 231).

12. Joel Robbins has reinterpreted the paramount value with a different visual analogy that is perhaps even more helpful. It is, for Robbins, like a "rather busy mobile with many separate and balanced arms that are all, in the last analysis, dependent upon and coordinated in their movement by a central string" (1994: 28).

13. This would suggest that while Dumont's relentless comparativism opened up fresh lines of inquiry, it also foreclosed others. 
paramount value by the dependence of their subalterns. Dependence is autonomy's functional complement-for if the directors were indeed totally autonomous they would be without the social and material support necessary to realize their scientific visions.

It is profoundly important to note here that this relation of complementarity has a remarkably long history in Germany. Indeed Fritz Ringer's salutary portrait (1969) of German universities at the end of the nineteenth century has many echoes with what we see taking place in the Max Planck Society today. The hegemony of the full professors (who also governed the institutions) was dramatically enhanced when enrolment boomed after the unification of Germany in 1871. While their numbers increased only marginally, those of associate professors and Privatdozenten (quite literally "private lecturers" - a hyper-precariat paid per lecture by each student who attended) grew significantly_further hierarchizing the dual regime of autonomy for some and dependence for others that had been institutionalized since the early nineteenth century.

It could of course be argued that norms of hierarchical dependence are emblematic of academic institutions in general-being, as David Graeber points out, "among the only institutions that survived more or less intact from the High Middle Ages" (2014: 77). After all, the need for professional references from one's elders never stops. Yet what is striking and comparatively unusual about the Max Planck Society is the widespread absence of tenure for post-PhD scientists in their 30 s and sometimes $40 \mathrm{~s}$, and moreover that this dependence is concentrated in one individual, rather than distributed among a community of superordinates. Before exploring its ethnographic consequences, let us now explore the transhistorical development of its values in further depth.

\section{The Society past and present}

When the Kaiser Wilhelm Society (or KWS) was founded in 1911, it was with two distinct characteristics. The first was that, unlike the universities, it drew its legitimacy not from the German state but from the German monarchy. Indeed the new organization was verily saturated in the symbols of kingship. Kaiser Wilhelm II not only gave his name and profile as emblems of the new organization but also its inaugural speech in which he offered his "protection" (cited in Vom Brocke 1990: 27). Kingship was there too implicitly in the form of social organization that the new institutes would adopt, each formed around a single leader drawn from the ranks of the intellectual elite. The second was that the KWS was to be an institution of great national significance, a pillar of Wilhelmine Sammlungspolitik (the politics of national cohesion) with the aim - much like the founding of the University of Berlin-of building an institutional apex to concentrate the intellectual achievements of the German nation. This moment is key because it is here that the Society's two paramount values are born-only today they are articulated rather differently. The values that survive are not kingship (which has been passionately repudiated) and patriotic supremacy (similarly so) but the more contemporarily acceptable values of autonomy and excellence. It is these that persist in the organization we know today. 
Of the two, it is the latter that impresses itself most visibly and quickly upon the passing stranger. Indeed in all of the Society's promotional literature its most pithy and pervasive description of itself is simply, "Germany's most successful research organization." One of the ways it tends to illustrate this is through the number of Nobel Laureates the Society has produced, bronze busts of whom populate the Institutes-a clear example of how its paramount values find expression in individuals. More broadly, like all effective values excellence takes on an almost air-like form inside the organization: the stranger is inhaling it even when he or she is not necessarily aiming to. It can be found in the striking and unorthodox modernist buildings in which the Institutes house themselves, in the sleek sheen of a newlypurchased instrument costing a cool 100,000 Euros, or in the clear-eyed exuberance of its student workforce. The Max Planck Society's drive for excellence does not attempt to conceal itself in secrecy or dissimulate through false humility; it is a value both bold and boldly stated. To enter the Society's administrative headquarters in Munich, the stranger must pass over a thin strip of water resembling a castle moat. Engraved on the stone bridge underfoot read two lines of ancient Greek, "Full of desire and love, always to be the best and distinguished above the sum of all others." 14

Autonomy, on the other hand, is a paramount value with a more subterranean existence. It lives beneath the surface but can be rapidly unearthed if one traces the organization's development through the last century. This may seem counterintuitive now, but at its inception autonomy was to be achieved by financing from private donors. The Kaiser Wilhelm Society would guard its separation from the state by appealing to individual and corporate sponsors drawn from the ranks of Germany's wealthy industrial class - many of whom were personal acquaintances of its founder and first president, Adolf von Harnack. This was in part because the turn of the twentieth century was a time of profound crisis for the German university system (Ringer 1969). That the Kaiser Wilhelm Society would be a purely research-oriented organization with only a negligible quantity of state funding was thus from the outset an effort to distance itself from the universities and their woes. It would be formally registered as a $\mathrm{GmbH}$ - a private rather than a public organization. ${ }^{15}$ One result of this was that the Society was exempt from the laws governing civil servants: a fact that intriguingly had several progressive consequences such as the legal employment of women and non-Germans.

State autonomy was to be short-lived however, as by the 1930s the Kaiser Wilhelm Society had become intimately embroiled in some of the Nazis' worst atrocities (Heim, Sachse, and Walker 2009). Perhaps unsurprisingly therefore, after its closure at the end of the war and subsequent rebirth with support from the allies (Oexle 1995) as the Max Planck Society in 1948, the desire for autonomy took on both a greater fervor (Ebersold 1998) and a wildly different form. Article 1.2 of its founding statutes recapitulated and extended this value in no uncertain terms. The

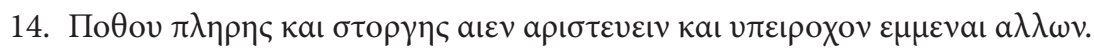

15. This stands for "Gesellschaft mit beschränkter Haftung," in English, "a company with limited liability." This particular legal status was established in Germany in 1892, and means that it is a private enterprise but also that the accountability for debts and bankruptcy falls to the state rather than the owners. 
Society was to be "a union of free research institutes, that belonged neither to the state nor to the economy. They shall carry out scientific research in full freedom and independence, being constrained not by contracts, but only by the rule of law" (Henning, Kazemi, and Ullmann1998: 17-18). ${ }^{16}$ Due to the nefarious activities of the KWG, which were partly enabled by the political medium of private sponsorship (including the notorious chemicals firm I. G. Farben), autonomy had to be asserted not simply from the German state but also from the potential corruptions of commercial interests. Instead of a $\mathrm{GmbH}$, the MPS thus began life as an eingetragener Verein (e.V)-a public organization. ${ }^{17}$ The agreement laid down in Königstein stipulated the financial arrangement that would secure this status: the Institutes were to be financed half by the federal government and half by the state in which each Institute is located. ${ }^{18}$ The Max Planck Society thus turned in the diametrically opposite direction from its predecessor in a financial sense, seeing the security of state funding (but with political intervention expressly prohibited) as the method to ensure the Institutes would remain "free." However the value of scientific autonomy not only successfully straddled the rupture between the two organizations but in fact grew stronger as a consequence of the rupture itself. The state-orchestrated horrors undertaken by the privately-funded KWS are some of the reasons why the MPS has been able to guard both its political and commercial autonomy so effectively thus far. ${ }^{19}$

The singular embodiment of these values by departmental directors is codified by the contemporary discourse of the Harnack Principle. The latter takes its name from the organization's founder, and offers a visible and well-defined idea of personhood through which the Society's form of social organization reproduces itself. Surprisingly, however, Harnack never inscribed a principle during his lifetime. It was in actuality "only after Harnack's death" in 1930 "that the principle became canonized" (Vierhaus 1996: 137), and has, in the decades since, been passed down through oral tradition by his successors. ${ }^{20}$ By examining the historical speeches of presidents and the testimonies of several standing directors, it can be thus interpretively formulated in the following terms. The Harnack Principle ostensibly signifies a process whereby an exceptional scientist is discovered by the directorial community, outside the borders of the organization, and at a relatively early stage of their

16. This is my translation of the original German: "Eine Vereinigung freier Forschungsinstitute, die nicht dem Staat und nicht der Wirtschaft angehören. Sie betriebt die Wissenschaftliche Forschung in völliger Freiheit and Unabhängigkeit, ohne Bindung an Aufträge, nur dem Gesetz unterworfen."

17. The principal difference between an e.V and a $\mathrm{GmbH}$ is that the former is explicitly noncommercial.

18. This arrangement is largely still in place, although as much as 20 percent of the Max Planck Society's funding now comes from "third parties," which include industrial sponsorship and patent royalties.

19. State funding of the Kaiser Wilhelm Society also substantially increased under the National Socialists.

20. This is my translation of the original German: "es ist eigentlich erst nach Harnacks Tod 'kanonisiert' worden." 
career (usually in their 30s or 40s). At this point they are invited to join the Society and to found a department from scratch, which will be accorded the space and the resources to spend the next twenty to thirty years pursuing a particular research direction. ${ }^{21} \mathrm{~A}$ more implicit aspect of the principle is that these individuals are not simply defining their own scientific research but also the character of the community performing it. This means hiring all of its scientific staff and deciding how to organize them; yet it can also mean determining what hours this staff works, their commensality rituals, and even what language they speak, whether German or English. ${ }^{22,23}$ The Max Planck Director thus maintains the classic Janus-face of the king (Sahlins 1981; Valeri [1980] 2014: 8-13): drawing authority from an external source, which is then translated internally.

Despite the continuity of the Harnack Principle since the 1930s, this is not to say it has gone unmodified or unchallenged. The 1960s and 1970s in particular were a turbulent time for the Society and its habits of self-governance. As mentioned, all of the Kaiser Wilhelm Institutes had been founded and organized around one central figurehead-eminent German scientists such as Albert Einstein and Max Planck himself-and this principle persisted after the war. It was only in 1964 that the directors sought to mollify the first wave of democratic critique by diluting this sharply tapered vision of leadership into the "collegial directorship" (Gerwin 1996: 211) recognizable today - in which an Institute will be governed by anywhere from two to five directors. As the 1960s marched on however, it was clear that for many this reform was inadequate. Public resentment for what was still considered a deeply autocratic institution was so pronounced that in 1968 students pelted the directors with eggs as they entered their general meeting (Gerwin 1996). Thereafter it became clear the organization would require more visible restructuring if it was to see the century out. Two major democratic measures were finally voted in in 1972, both of which operate energetically today. The first of these is the Fachbeirat or external advisory board: a form of audit culture avant-la-lettre in which established scientists outside the Society are invited biannually to survey the work of the Institutes and submit a report to its president documenting their findings and recommendations. The purpose of the Fachbeirat is to exert reputational pressure on the directors to impress the board with their research outputs but also to dangle the threat of a possible cut in funding by the president if the report is a very negative one (although this is rare). The second measure was the introduction of a Betriebsrat or union, a representative body that all employees (excluding the directors) are permitted to join. Again, the Betriebsrat was similarly designed to constrain the

21. My description is of a largely adhered-to ideal. This does not mean, however, that it is not contravened in all sorts of ways, not least by the fact that no less than eleven directors at the time of research ascended to the position directly from other Max Planck Institutes.

22. In some departments scientists are obliged to be present in their Institute at specified times, while others offer more flexibility in when and where scientists are able to perform their contracted hours.

23. My impression was that most directors chose English rather than German as their lingua franca-one recently corroborated by current President Martin Stratmann in an interview with Die Zeit (Spiewak 2015). 
power of the directorships, who until that point could run the Institutes in whatever manner they chose.

So far, so progressive. Nonetheless it is difficult to see what effect these reforms have in practice on the scientific staff who are our concern here. The directorship may have become collegial, yet the directors are still the formal heads of the administration, meaning among other things that they have the final say on all matters of recruitment. The Fachbeirat may push the directors to keep the research standards of the Institutes high, yet the directors are still the primary authority that decides what this research will be. And the Betriebsrat may be a venerable and necessary social institution, yet in those Institutes I visited, these are dominated by the technical and administrative staff. Indeed, one union organizer, herself an administrator, admitted to me that the scientists "don't see it as a committee for them." This is, of course, a matter of choice; however it is not hard to entertain the idea that the highly personalized scientific relations of the departments might work against taking recourse in formal representation.

In short, what examining the long history of the organization shows us is the "persistence and transformation" of its hierarchy (Rio and Smedal 2009), which is enacted through a changing discourse of values. The transformations are self-evident. The KWS begins life as an unabashed genuflection to monarchy (even retaining the Kaiser's profile as its heraldic symbol long after the latter had in fact abdicated the throne), which is mirrored in the single-headed Institute. As the century continues (particularly after 1945) the values of kingship and private sponsorship as counterpowers to the German state are substituted for an increasingly reified discourse of "freedom" or autonomy from both state and industry, with Harnack rather than the Kaiser as its myth of origin. The tiny kingdoms of the institutes are subsequently split up into "collegial" directorships, and the power of the directors constrained by representative bodies. Of course, this discourse continues to evolve. The most recent perceptible shift is of President Martin Stratmann's use of Harnack's early vision to dissolve the boundary between basic and applied science (2014): a development that may presage the encouragement of closer links between directors and corporate actors.

Yet what is perhaps more interesting is the persistence of an older hierarchical form in the midst of this flurry of change, one that anthropologists have theorized as "kingship." 24 As I see it, the directorship ultimately possesses two major strands of continuity with this form. To begin with, the director's appointment operates through the logic of kingly externality (whether Valeri's "extraneous" authority [(1980) 2014: 8], Sahlins's "stranger-kingship" [1981] or Graeber and Col's "life from the outside" [2011: xx]). Extraordinary value is placed on the fact that directors are supposedly drawn from beyond the borders of the organization, any semblance of inheritance being strictly taboo. ${ }^{25}$ While directors diverge from Sahlins's

24. The historical antecedents to the directorship I cited in the introduction all operated formally as kingships although they were not all named as such.

25. This is of course distinct from the many forms of kingship based on genealogical right. Indeed it is the institutionalization of stranger rather than autochthonous kingship that is the starkest point of divergence between the directorship and the old feudal monarchies (cf. Valeri [1980] 2014: 25). 
famous formulation (1980) in the sense that there is no society that precedes their arrival, they maintain this insider/outsider relation in their departments. One director remarked that they occupied a "strange and hybrid position." Deriving from such sacred externality is the directorship's second and most significant strand of continuity: that is, its retention of the king's position as the essence of relatedness, and thus the source of social and cultural generativity (Graeber and Col 2011: xxiii; Valeri [1980] 2014: 1; Warnier 2007). Post-PhD scientists would certainly recognize in their departmental relations Declan Quigley's definition of the monarchical community, i.e., that "everyone is united by his or her common relation to the king" (2005: 5). It is this persistent centrality of the director that makes the Society's repeated use of Harnack to transform its own values so interesting. By situating one individual (and incidentally, a Prussian German male) as the sole author of collective transformation, each iteration undertakes the mythological work necessary to maintain the symbolic force of the directorships. What Ferguson calls "liberal common sense" (2013: 237) has hence been held at arm's length, underlying relations of dependence upon this key figure persisting unpathologized. To survive professionally in the Max Planck Society, post-PhD scientists must therefore steer this mode of action in their favor. Now we turn to three cases of such efforts.

\section{In the Institute for Nanoscience ${ }^{26}$}

In 2010, I spent seven months at the Max Planck Institute for Nanoscience in the bucolic outskirts of Berlin. ${ }^{27}$ As many of its employees chose to lead urban lives in the city-just as I did-I got to know several of them on the commute into work. Each morning the scientists and I would tumble off the train at the station to begin the ten-minute stroll in. As the sun beat down in summer we chatted convivially in t-shirts and sunglasses as we walked, enjoying the delightful sight and scent of wild flowers hugging the long road. In winter the scene was rather bleaker. Armed with thick winter coats against an easterly wind and subzero temperatures, we crunched silently toward the Institute along a narrow passage in the snow. In all weathers a few hundred meters beyond the station the straight road curved to the left, and the

26. This is a fictional institute in order to safeguard the anonymity of my research participants. Some details have been changed.

27. My methodology would be recognizable to any anthropologist of science, based as I was in a department in the Institute that undertook a mixture of experimental and computational work. This meant spending three or four days a week accompanying scientists and technicians during lab experiments, attending group meetings and departmental seminars, and engaging members in a mixture of formal and informal interviews (a total of fifty-eight of the former across the Institute as a whole). I also spent four days away from Berlin-Brandenburg with the department on their annual "retreat" (Klausur). It is epistemologically relevant to note here that my ethnographic conversations extended to the Institute's directors, including several with the director of the department where I was based, and also that I was formally prohibited from attending the meetings between the latter and his cohort of group leaders. For further particularities on method please see Peacock (2013). 
Institute's compound of buildings came into view, until then occluded by the boxy grey and blue start-up companies erected alongside it. Its aesthetic was exquisitely high-modern, with a carapace of dark grey corrugated iron, lined with unabashedly exuberant strips of yellow, pink, orange, green, and blue.

Inside, the appetite for exuberance continued. Murky pinks, terracotta oranges, and ocean blues covered the walls, while framed Technicolor scientific photographs hung from them like artworks. A series of over-large shrubs were planted directly into the ground floor, wonderfully disturbing the boundaries between inside and out, and a capacious airy library with glass walls on three levels looked out over them. Everywhere, large windows gave it a generous, open feel. The Society's drive for excellence is thus not purely of the dry and easily audited kind but rather has strong colorful and nonrational aspects. Indeed, on walking through the main areas of the Institute, the visitor was saturated with a vivid sense of scientific "excitement" (Begeisterung) that the organization claims is what drives it.

Color came to an abrupt halt, however, at the entrances to the corridors down which the scientists trickled to reach their labs and offices. Austere greys and whites clearly demarcated these spaces as sites of scientific production. At the end of each corridor sat a small breakout area with coffee-making facilities and several chairs around a table. Much like the library, the walls were again lined floor-to-ceiling with glass, meaning that of those facing over the internal courtyard, one's gaze was naturally drawn to a large metal sculpture at its center. Two metal cuboid poles, each several meters high and planted separately on an axis in the ground, swung in long graceful arcs around each other as the wind steered them: an assemblage that seemed to capture both the robustness and fragility of life inside the Institute.

The MPI for Nanoscience was founded in 1994, as part of a wave of expansion into the former East Germany, and has been growing steadily ever since. During my visit, there were four departments and thus four directors, managing a total of just over 300 employees. The department in which I spent much of my time hosted fifty-six of these: of which eight were group leaders and four were independent researchers. ${ }^{28}$ These senior positions are structurally similar in the sense that their occupants are often of a similar age and on roughly the same salary scale. However, the group leaders are modestly preeminent as they will have a formal team of students and postdoctoral fellows focused on their own research interest, while independent researchers will usually work with other members of the department in a more loosely collaborative way. An independent research fellowship may also be a stepping stone into a group leader position; and thus the distinction between them can serve as a way to circumvent the "soft maximum" of five years in which any scientist (bar the directors) is usually permitted to stay in the Society. It was the wildly different experiences of three of these organizational persons that I shall now zoom in on. ${ }^{29}$

28. An "Independent Researcher" is an emic term referring to a post-PhD scientist who neither holds a Postdoctoral Fellowship, nor a Group Leader position.

29. It will be noted that all three individuals are male, although there is no mono-causal explanation for this. Statistically there are fewer women in the Institute at the post$\mathrm{PhD}$ level, constraining the pool of possible participants. However, it may equally be, as Victor Buchli has suggested (pers. comm.), that crossgender fieldwork relationships 
Axel was a group leader in his forties, who had been hand-plucked by the director from the Germanophone city they both lived in, to help him initiate the department ten years previously. He was tall and full of life: a smile never far from his face and a joke never far from his speech, with a passion for natural science so infectious that even I got momentarily caught up in it. He was a long-term friend and colleague of the director, and although they came from separate fields, the two had already penned a number of key articles together as the sole coauthors. As the primary "stranger handler" (Agar 1980: 59) of the community—which as Michael Agar notes, is a position always indexing trust and high status-it was Axel who was placed in charge of my stay. His profound identification with the department was clear; when we crossed the threshold to another in the Institute he half-jokingly referred to it as "enemy territory." Axel's perspective on the internal life of the department was thus of unqualified praise. "Not all research is as harmonious as in this department," he told me knowingly one day. They were fortunate because in theory the director "could be a king if he wanted to"; yet "you do not feel it because he is very democratic."

Axel was unequivocally in a position of desirable dependence, having well surpassed the Society's temporal soft maximum to a departmental position of de facto permanence. He was clearly unperturbed by his own formal encompassment by his colleague. The latter could have been a king but was not, implying Axel did not sense a political disparity matching the hierarchical, echoing Dumont's distinction between status and power. One aspect of his experience is particularly instructive: the possession of a degree of distance from the skills and interests of the director. The latter was of an experimentalist bent, while Axel was highly theoretical. Indeed, when speaking to them together one sensed a strong divergence in their proclivities but also the way that it facilitated a fizzing synergy. Despite remaining loyal to the director's vision, Axel had therefore always had his own ideas and methods. He showed that the best way to navigate dependence was to carve out as large a space of autonomy as was possible within it.

Benjamin was also a male scientist in his forties, but this time an independent researcher of lesser longevity who cut a rather different figure. He expressed himself with more austerity than Axel and could be quick to temper, but his loquacious and avuncular manner made him popular with the younger students. Benjamin joined the department from Spain in 2006 through a personal link to the director, who was distantly connected to some of the research he was doing there. The agreement they had negotiated before his arrival was from the outset a compromise: Benjamin had some "fascinating questions" he wanted to answer on one topic, while the director was keen for him to use his expertise to pursue another. In the end they mutually agreed he could work on both and see how things progressed. For a long while Benjamin clearly thrived in the creative and technologically firstrate environment that the MPS could be. He had built eight separate experimental machines from scratch-each serving the purpose of answering its own specific scientific question - and told me that such a high degree of innovation would have been unheard of at his previous institution, where they would trundle out the same

are more generative, or more provocatively, that women are more likely to be culturally inscribed to accept dependence and therefore less reflective on the relation. 
old devices for years on end. There at the Institute one felt one was really doing "hardcore science." At times, jarring curiously with these bursts of enthusiasm, Benjamin would veer off into nostalgic soliloquies of social decay. The informational anarchy wrought by the Internet would spell the end of traditional pedagogy, he was sure. The trouble with modern science is that it is completely technologically determined, he avowed. Their underlying theme was always of a deterioration of human agency in some or other realm from its prior state of realization. I did not give much thought to these at the time; it was only the following year on returning to the Institute that I began to feel that something else was being communicated.

Over cups of tea in his tall-ceilinged Berlin apartment, Benjamin and I talked at length about the hierarchical arrangement of the Max Planck Society, in which he was adamant he did not "fit." In stark contrast to Axel, for Benjamin the organization maintained a very rigid division of labor. "You have a director who gives general directions but then meets with his deputies, and then they execute their director relations with the PhDs and postdocs, who then work with the technicians." The subject led him naturally to the predicament faced by those in his position-independent researchers and group leaders - whom he called the "intermediate tier." ${ }^{30}$

"The whole pressure is on the intermediate tier. Three to six years after completing your (doctoral) degree, you are expected to enter this intermediate tier. But up to ten years after completing your degree, you are expected to no longer be there. Because if you do get stuck there, there are legal issues and the MPI has to take you on as a permanent employee which is not going to happen."

Benjamin's testimony was not completely accurate. There are permanent positions available for this tier, although they are comparatively rare and depend on what one can "negotiate" with the director in question. ${ }^{31}$ Yet this sense of a ticking clock was quite common among scientists at his level. Benjamin now realized the director was never going to permit him to pursue his "fascinating questions" by awarding him a group leader position; thus the only option that remained to him was to exit the organization entirely. I inquired about possible next steps, but Benjamin was recalcitrant. He resisted discussing the future and warned me away from such a "pungent topic." After a couple of hours I left his apartment beset by some anxiety I could not name. Later that night I woke up at 4am with a start-something I rarely do. The nightmare I had fled involved the two of us talking in his apartment together when the director suddenly loomed into the scene, the charge between them somehow baleful. Soon after I bid my final farewell to the Institute I discovered that Benjamin had left not long afterward, his five years finally up.

Everything Benjamin said points to his experience of dependence as a mode of inaction. His word choices alone reveal much: the MPS is a place one gets "stuck"; its social structure is compared to an army; the question of his next move is nothing less than effluvial. Moreover the psychological troubles familiar to precarity theorists are clearly manifest. The absence of any "shadow of the future" (Standing

30. In German this hierarchical level is sometimes referred to as the Mittelbau.

31. I am informed by the administration that the director is "free to decide" whom s(he) wants to offer a permanent position - if $s($ he) has a free position covered by his or her budget. The only limiting factor is that the director cannot make any more permanent appointments five years before retirement. 
2011: 20), and an existential anxiety (which seeps its way into my dreamscape) appear frequently among those on temporary contracts. What is particular about precarity here, however, is that these were all direct consequences of a primary relation between him and the director. Indeed Benjamin's case is a salutary example of how personalized this relation can be. Without one individual's willingness to encompass his research, his capacity for action inside the entire organization had evaporated. It is subsequently not as Ferguson's argument would suggest, that in the achievement of dependence alone possibilities for advancement are necessarily opened up. Dependence in the MPS can be highly undesirable, if the delicate balance of autonomy and encompassment between these two scientists is not reached.

Of the three, Faris had been employed in the department for the shortest time: just two years. Originally from a war-torn nation in the Middle East, he was a gregarious and bear-like fellow, with a nimbus of black curls framing a benevolent face. Like Benjamin, Faris was an independent researcher. Nevertheless what distinguished him from Benjamin (and indeed from Axel) was that the dust had not yet settled on his relationship with the director. My stay in the department coincided with a critical professional moment for him, in which he was delicately negotiating his position in the department: a process that would have profound medium-term - and even long-term-implications. Faris's experience consequently enables us to see in practice how the dependence relation can be manipulated by the dependent to the mutual advantage of both parties.

Like many scientists in the department, Faris was characteristically affable: his countenance curved constantly upward into a slightly sheepish grin. I was surprised therefore to find him on the day of our discussion slumped slightly at his desk, surrounded by an atmosphere of mild despair. I did not have to inquire as to the provenance of this grey mood as he immediately began to explain his predicament. When he had first arrived in the department it was as a specialist in nanotubes and so at the behest of the director a technician had purchased the equipment he needed to investigate them, assembled everything, and was in charge of operating it. Then the technician left. The vacancy thus fell naturally to Faris as the only other person there with the necessary expertise, and since then he had been training other scientists in the department to use it and assisting them with their experiments alongside his own. While he enjoyed this he realized it placed him in a bind. "I got really into it and became this technique-oriented guy, and now this is what I'm fighting every single day. I'm not a technician and I'm not going to be a technician." Faris was in the eye of the storm Benjamin identified, which envelops "the intermediate tier": i.e., that in three years' time he will be expected to "no longer be there" and time was running out. Although his name appeared on an impressive proportion of the publications the department produces, this was for technical assistance rather than intellectual authorship; he was acutely conscious it was only the latter that would ensure his professional survival in the field. Faris ended our talk with what sounded like a solemn injunction to his future self, "One must be careful to define one's own piece of cake, and not be part of someone else's piece of cake."

When we met again many months later, it was manifest this injunction must have worked. In the intervening period Faris had managed to maneuver himself 
into an advantageous position, from which he would "be able to compete" for a university post. He would not formally be a group leader but would have a small cluster of PhD students and perhaps a postdoctoral fellow around him and his research interests, according him the requisite intellectual distance from the director to secure his own future. Now-he informed me-he had several publications on which the director was not the coauthor, and felt "much more confident" as a result because it showed he had his "own ideas" rather than simply "copying." This was not necessarily a linear process. Faris was "lucky" because the experiments he carried out with his technique were a categorical success, and the director could clearly witness a wealth of scientific potential opening up. This meant it was easier to "convince [the director] that it was a nice project." Now convinced, however, the support the director was giving him was unequivocal. The latter "will fund everything I am doing" and is "giving me incredible freedom," Faris gushed. His positivity in that moment was undiluted, and scaled up to encompass his views on the organization and science in general. Instead of the rigid quadripartite structure outlined by Benjamin, he-like Axel-emphasized the department's "relaxed" character. Instead of those parables of constraint, Faris confidently asserted that as a scientist "our only job is being creative." Faris now knew that when his five years expired there was a good chance he would move into a university position or be given a contract to stay longer, and the brightness of this imagined future illuminated his every utterance.

The processual nature of Faris's testimony demonstrates a further aspect of dependence, less stark in the previous examples. Whether consciously or not, he has clearly solved the problem of value inside the MPS and is strategizing his way through it. In so doing, Faris offers an ethnographic critique of Dumont and of structuralism in general: that, as Rupert Stasch points out, people do not simply live "within" sets of cultural ideas but also utilize these self-same ideas to "craft judgements and take positions" (2002: 337).$^{32}$ Faris was highly reflexive about how the organization "works"-but rather than admonishing dependence through the prism of liberal common sense he had instead constituted it as a classic Fergusonian mode of action. He was carefully placing himself into an excellent position from which to make the leap to the universities: the ideal trajectory that the Society would wish for its post-PhD staff.

Before concluding the discussion it is worth pointing out that the Harnack Principle does not simply shape the personhood of directors. Rather, like all discourses of value it tumbles through the social order. Faris was similarly asserting both autonomy and excellence from within his own hierarchical position. He had carved out his "own piece of cake" using his "own ideas," and evidencing great scientific success in the process. Nevertheless we should still not confuse encompassed and encompassing values. Faris's autonomy remained qualitatively different to that of the director. Just that simple phrase "he is giving me incredible freedom" tells us all-that the capacity for action is a hierarchical gift, not a universal right. The Max Planck Society is not populated by abstract liberal individuals but instead by

32. As Iteanu and Moya rightly point out, "Dumont is not terribly interested in the Indian person qua agent" (2015: 122). 
persons suspended in webs of functional complementarity. It is then from within these webs that they may be able to weave their way into positions of temporal security.

\section{Conclusion}

The comparatively extreme precarity of scientists in the Max Planck Society has been widely discussed in the German media (Reif 2012; Müller 2012), as indeed has its social "formula" (Kröher 2013) and the possible pitfalls thereof (Grünewald 2014). What remains underdiscussed and undertheorized, is that these two phenomena are created in the very same movement. The Society's discourse of autonomy-enshrined in its founder's purported "principle"-is as pronounced a discourse of dependency as it is of autonomy, only that the latter is never explicitly articulated. Particularly in the natural sciences that have been our focus, fully qualified researchers are indispensable to an intellectual division of labor that serves to realize the director's vision. Autonomy and dependency are thus not only fundamentally linked, but in fact coproduce one another in their very emergence. This would indicate that solving problems of precarity among MPS scientists is not simply a question of lengthening contracts, as these reports would suggest, but one that-if it is to have enduring success-must confront the institutionalization of inherited ideas of intellectual leadership.

Such syllogistic reasoning is potentiated by a Dumontian analysis that places persons before people. Rather than navigating some kind of representational void, it means that people act-often reflexively-from within social functions prescribed to them. Personhood does not remain static, however, and the centurylong history of the organization demonstrates the changing discourse of values therein-one that has produced slightly different models of personhood over the years. Nevertheless, what has persisted to the present day is a conception of the professional dependency of some persons upon others, dependencies that are now frequently expressed through a neoliberal preference for temporary working contracts.

Nevertheless, it is important to stress in these final remarks that like any social organization with a more or less coherent set of values, the MPS is morally ambivalent. Here Ferguson's contribution has been invaluable. He makes a selfconsciously provocative claim by stressing the ethnographic existence of "desirable" dependence, and it is one that has shed a similar light here. Indeed it is only by de-pathologizing dependence that the positive professional outcomes for Axel and Faris can be fully understood. Encompassment by a given director may open up a mode of action if subaltern staff are able to cannily assert their own autonomy and excellence within it, just as Faris's success with his technique is not subsumed by the director's research outputs (although no doubt assisting a positive appraisal in the Fachbeirat), but becomes a way for him to advance professionally within and beyond the organization. Yet the case of Benjamin obstructs an interpretation of dependence as unequivocally desirable. With its roots in German monarchy, that the scientific whole is encompassed by a single individual means that the dependence relation is profoundly individualized, as it is not in Ferguson's southern African 
case. Dependency's relative desirability then becomes contingent upon the quality of this interpersonal encounter. Shortly before I left the Institute for Nanoscience, a PhD student remarked to me that she found it surprising that Axel was permitted to stay beyond the five-year term while Benjamin was not. Compared to other academic institutions it was indeed surprising, but within the Max Planck Society it was simply one rational outcome of an internal logic of individualized dependency. If post- $\mathrm{PhD}$ staff fail to harmonize to the obligatory relation of individual encompassment, they must accept the inevitability of social death.

Considering precarity as dependence, however, has implications beyond this German organization. It possesses the potential to rechannel the intellectual resources recovered by Ferguson into new social and political resources. For if a position of precarity in the form of temporary employment is equivalent to a social condition of hierarchical dependence, then it can no longer be an epiphenomenon of impersonal neoliberal forces. In fact, it would suggest that the framing hitherto, of precarity as somehow impersonal works in practice to exculpate the specific actors driving its distribution across the world. In the Max Planck Society at least, the intimacy of this relation can give directors a strong sense of responsibility to those who depend on them. In the wider world such reciprocities may be harder to trace but that makes it all the more pressing that we do so. Only by suturing apparently discrete human situations - of precarity and security, or autonomy and dependency, or even of land-ownership and tenancy-will we be able to live ethically and to hold those who have power to account.

\section{Acknowledgments}

I would like to thank the four anonymous reviewers who offered important and helpful critiques, as well as to Giovanni da Col for his editorial advice. Similarly, this inventio could not have arisen without the pedagogical instincts of my doctoral supervisor, Susanne Kuechler, who always nudged me away from easy and fashionable interpretations of fieldwork. I must thank the following bodies for financing the research period-The Royal Anthropological Institute, The Schools Competition Act Settlement Trust, and The Department of Anthropology and Graduate School of University College London-and am similarly grateful to the Economic and Social Sciences Research Council for financing the period of writing. Finally, I would like to express my profound thanks to all of the Max Planck Society employees who were willing to engage with this project, both inside the Institute for Nanoscience and elsewhere.

\section{References}

Agar, Michael H. 1980. The professional stranger: An informal introduction to ethnography. New York: Academic Press.

Baker, Tom, and Jonathan Simon. 2002. Embracing risk: the changing culture of insurance and responsibility. London: University of Chicago Press. 
Beck, Ulrich. 1992. Risk society: Towards a new modernity. London: Sage.

Berlant, Lauren. 2011. Cruel optimism. Durham, NC: Duke University Press.

Bolt, Maxim. 2013. "The dynamics of dependence." Journal of the Royal Anthropological Institute 19 (2): 243-45. doi:10.1111/1467-9655.12024.

Bonilla, Oiara. 2013. "Be my boss!' Comments on South African and Amerindian forms of subjection.” Journal of the Royal Anthropological Institute 19 (2): 246-47. doi:10.1111/1467-9655.12025.

Born, Georgina. 1995. Rationalizing culture: IRCAM, Boulez, and the institutionalization of the musical avant-garde. Berkeley: University of California Press.

Bosworth, Derek L. 1991. Employment contracts, job tenure and work histories: Precarious employment in the UK. IER Discussion Papers, no. 46. Coventry: University of Warwick, Institute for Employment Research.

Bourdieu, Pierre. 1988. Homo Academicus. Stanford, CA: Stanford University Press.

Boyer, Dominic. 2005. Spirit and system: Media, intellectuals, and the dialectic in modern German culture. Chicago: University of Chicago Press.

Butler, Judith, and Athena Athanasiou. 2013. Dispossession: The performative in the political. Cambridge: Polity Press.

Da Col, Giovanni, and David Graeber. 2011. "Foreword: The return of ethnographic theory." HaU: Journal of Ethnographic Theory 1 (1): vi-xxxv. doi:10.14318/hau1.1.001.

Deakin, Simon. 1986. "Labour law and the developing employment relationship in the UK." Cambridge Journal of Economics 10 (3): 225-46.

Diefenbach, Thomas, and John A. A. Sillince. 2011. "Formal and informal hierarchy in different types of organization." Organization Studies 32 (11): 1515-37. doi:10.1177/0170840611421254.

Dumont, Louis. 1980. Homo Hierarchicus: the caste system and its implications. Complete revised English edition. Chicago: University of Chicago Press.

-1986. Essays on individualism: Modern ideology in anthropological perspective. Chicago: University of Chicago Press.

- 1994. German ideology: From France to Germany and back. Chicago: University of Chicago Press.

Dyck, Noel. 2014. "Working the boundaries: Anthropology and multidisciplinarity in Canada." Etnográfica. Revista Do Centro Em Rede de Investigação Em Antropologia 18 (2): 255-73. doi:10.4000/etnografica.3665.

Ebersold, Bernd. 1998. “50 Jahre im Dienst der Gesellschaft: Zur Entwicklung der MaxPlanck-Gesellschaft als Forschungsorganisation.” In Forschung an den Grenzen des Wissens: 50 Jahre Max-Planck-Gesellschaft 1948-1998, edited by The Max Planck Institute for the Advancement of Science, 155-75. Göttingen: Vandenhoeck \& Ruprecht.

Englund, Harri. 2013. "Reclaiming the anthropology of claim-making." Journal of the Royal Anthropological Institute 19 (2): 248-49. doi:10.1111/1467-9655.12026. 
European Foundation for the Improvement of Living and Working Conditions. 1997. Precarious Employment and Working Conditions in the European Union. Luxembourg: Office for Official Publications of the European Communities.

Ferguson, James. 2013. "Declarations of dependence: Labour, personhood, and welfare in Southern Africa." Journal of the Royal Anthropological Institute 19 (2): 223-42. doi:10.1111/1467-9655.12023.

Fraser, Nancy, and Linda Gordon. 1994. "A genealogy of dependency: Tracing a keyword of the U.S. welfare state." Signs 19 (2): 309-36. http://www.jstor.org/stable/3174801.

Garland, Christian. 2008. “The McDonaldization of higher education?” Fast Capitalism 4 (1). https://www.uta.edu/huma/agger/fastcapitalism/4_1/garland.html.

Garsten, Christina. 1994. Apple world: Core and periphery in a transnational organizational culture. Stockholm: Department of Social Anthropology, Stockholm University.

Gerwin, Robert. 1996. "Im Windschatten der 68er ein Stück Demokratisierung: Die Satzungsreform von 1972 und das Harnack Prinzip." In Die Kaiser-Wilhelm / Max Planck Gesellschaft und ihre Institute. Studien zu ihrer Geschichte, edited by Bernhard Vom Brocke and Hubert Laitko, 211-24. Berlin: de Gruyter.

Giroux, Henry. 2014. Neoliberalism's war on higher education. Chicago: Haymarket Books.

Graeber, David. 2014. "Anthropology and the rise of the professional-managerial class." HAU: Journal of Ethnographic Theory 4 (3): 73-88. doi:10.14318/hau4.3.007.

Groat, Craig. 2015. “The effects of neoliberalism on the academy." https://allthelittleworlds. wordpress.com/2015/01/12/the-effects-of-neoliberalism-on-the-academy/.

Grünewald, Sven. 2014. "Max-Planck-Gesellschaft: Im Zweifel hat der Direktor recht." Frankfurter Allgemeine Zeitung. October 22. http://www.faz.net/aktuell/feuilleton/ forschung-und-lehre/nachwuchssorgen-in-der-max-planck-gesellschaft-13220330. html.

Hall, Elizabeth F., and Todd Sanders. 2015. "Accountability and the academy: Producing knowledge about the human dimensions of climate change." Journal of the Royal Anthropological Institute 21 (2): 438-61. doi:10.1111/1467-9655.12162.

Harvey, David. 2005. A brief history of neoliberalism. Oxford: Oxford University Press.

Haynes, Naomi. 2013. “Desirable dependence, or what we learn from Pentecostalism." Journal of the Royal Anthropological Institute 19 (2): 250-51. doi:10.1111/1467-9655.12027.

Heim, Susanne, Carola Sachse, and Mark Walker, eds. 2009. The Kaiser Wilhelm Society under National Socialism. Cambridge: Cambridge University Press.

Henning, Eckart, Marion Kazemi, and Dirk Ullmann, eds. 1998. 50 Jahre Max-PlanckGesellschaft zur Förderung der Wissenschaften. Berlin: Duncker \& Humblot.

Iteanu, André, and Ismaël Moya. 2015. "Introduction: Mister D.: Radical comparison, values, and ethnographic theory." HAU: Journal of Ethnographic Theory 5 (1): 113-36. doi:10.14318/hau5.1.006.

Kapferer, Bruce, ed. 2005. The retreat of the social: The rise and rise of reductionism. New York: Berghahn Books. 
Knowles, Caroline, and Roger Burrows. 2014. “The impact of impact." Etnográfica: Revista Do Centro Em Rede de Investigação Em Antropologia 18 (2): 237-54. doi:10.4000/ etnografica.3652.

Kondo, Dorinne K. 1990. Crafting selves: Power, gender, and discourses of identity in a Japanese workplace. Chicago: University of Chicago Press.

Kröher, Michael. 2013. “Die Erfolgsformel von Max Planck.” January 9. http://www.manager-magazin.de/magazin/artikel/a-873864.html.

Kunda, Gideon. 1992. Engineering culture: Control and commitment in a high-tech corporation. Philadelphia: Temple University Press.

Latour, Bruno. 2010. The making of law: An ethnography of the Conseil d'Etat. Cambridge: Polity.

Law, John. 1994. Organizing modernity. Oxford: Blackwell.

Li, Tania Murray. 2013. "Insistently seeking social incorporation." Journal of the Royal Anthropological Institute 19 (2): 252-53. doi:10.1111/1467-9655.12028.

Mahmood, Saba. 2005. Politics of piety: The Islamic revival and the feminist subject. Princeton, NJ: Princeton University Press.

Maroudas, Leonidas, and Evangelos Nikolaidis. 2013. "Institutional changes and the expansion of flexible forms of employment in higher education: The case of Greek universities." JCEPS 11 (3): 127-45.

Martin, Keir. 2014. "Afterword: Knot-work not networks, or anti-anti-antifetishism and the antipolitics machine." HAU: Journal of Ethnographic Theory 4 (3): 99-115. doi:10.14318/ hau4.3.009.

Max Planck Society for the Advancement of Science. 2013. “The Max Planck Approach.” http://www.mpg.de/39586/MPG_Introduction?page=2.

Mitchell, Jon P. 2014. "Anthropologists behaving badly? Impact and the politics of evaluation in an era of accountability." Etnográfica: Revista Do Centro Em Rede de Investigação Em Antropologia 18 (2): 275-97. doi:10.4000/etnografica.3673.

Mitchell, Jon P., and Noel Dyck. 2014. "Introduction: Anthropology and the neoliberal agenda." Etnográfica: Revista Do Centro Em Rede de Investigação Em Antropologia 18 (2): 233-36. doi:10.4000/etnografica.3637.

Müller, Christine Xuân. 2012. "Wissenschaftler in Nöten Jung, Talentiert, Frustriert." Spiegel Online. http://www.spiegel.de/karriere/berufsleben/wissenschaftler-in-noetenjung-talentiert-frustriert-a-818994.html.

Oexle, Otto Gerhard. 1995. The British roots of the Max-Planck-Gesellschaft. London: German Historical Institute London.

Oxford English Dictionary. 2014. "Precarious, Adj.” OED Online. Oxford University Press. http://www.oed.com.libproxy.ucl.ac.uk/view/Entry/149548.

Peacock, Vita. 2013. "We, the Max Planck Society: A study of hierarchy in Germany." Doctoral Thesis: University College London.

2015. "The negation of hierarchy and its consequences." Anthropological Theory 15 (1): 3-21. doi:10.1177/1463499614564887. 
Povinelli, Elizabeth. 2006. The empire of love: Toward a theory of intimacy, genealogy, and carnality. Durham, NC: Duke University Press.

Quigley, Declan. 2005. The character of kingship. Oxford: Berg.

Reif, Franziska. 2012. "Wissenschaft Prekär Kettenjobber, Leiharbeiter, Forschungsknechte." Spiegel Online, May 29. http://www.spiegel.de/karriere/berufsstart/wie-junge-wissenschaftler-an-den-unis-geknechtet-werden-a-835467-2.html.

Ringer, Fritz K. 1969. The decline of the German Mandarins: The German academic community, 1890-1933. Cambridge, MA: Harvard University Press.

Rio, Knut Mikjel, and Olaf H. Smedal. 2009. "Hierarchy and its alternatives: An introduction to movements of totalization and detotalization." In Hierarchy: Persistence and transformation in social formations, edited by Knut M. Rio and Olaf H. Smedal, 1-63. Oxford: Berghahn.

Robbins, Joel. 1994. "Equality as a value: Ideology in Dumont, Melanesia and the West." Social Analysis 36: 21-70. doi:10.2307/23171803.

_. 2015. "Dumont's hierarchical dynamism: Christianity and individualism revisited." HAU: Journal of Ethnographic Theory 5 (1): 173-95. doi:10.14318/hau5.1.009.

Rodgers, Gerry, and Janine Rodgers, eds. 1989. Precarious jobs in labour market regulation: The growth of atypical employment in Western Europe. Brussels: International Institute for Labour Studies, Free University of Brussels.

Ruberry, Jill. 1989. “Precarious forms of work in the United Kingdom.” In Precarious jobs in labour market regulation: The growth of atypical employment in Western Europe, edited by Gerry Rodgers and Janine Rodgers, 49-74. Brussels: International Institute for Labour Studies, Free University of Brussels.

Sahlins, Marshall. 1981. “The stranger-king: Or Dumézil among the Fijians.” The Journal of Pacific History 16 (3): 107-32. doi:10.2307/25168469.

Shah, Alpa. 2013. "The anti-politics of 'Declarations of Dependence." Journal of the Royal Anthropological Institute 19 (2): 254-55. doi:10.1111/1467-9655.12029.

Skeat, Walter W. 1910. An etymological dictionary of the English language. New revised English edition. Oxford: Clarendon.

Spiewak, Martin. 2015. "Das ist einmalig." ZEIT ONLINE. April 9. http://www.zeit. de/2015/13/max-planck-institut-doktorand-forschung.

Standing, Guy. 2011. The Precariat: The new dangerous class. London: Bloomsbury Academic.

Stasch, Rupert. 2002. "Joking avoidance: A Korowai pragmatics of being two." American Ethnologist 29 (2): 335-65. doi:10.1525/ae.2002.29.2.335.

Strathern, Marilyn. 2000. Audit culture: Anthropological studies of accountability, ethics, and the academy. London: Routledge.

Stratmann, Martin. 2014. “Mehr Harnack wagen.” Max Planck Forschung 2: 10-15.

Teeuwen, Rudolphus, and Steffen Hantke. 2007. Gypsy scholars, migrant teachers and the global academic proletariat: adjunct labour in higher education. New York: Rodopi.

Thompson, E. P. 1963. The making of the English working class. London: V. Gollancz. 
Valeri, Valerio. (1980) 2014. “Kingship.” HaU: Classics of Ethnographic Theory Series 2 (1): $1-34$.

Vierhaus, Rudolf. 1988. Germany in the Age of Absolutism. Cambridge: Cambridge University Press.

_. 1996. "Bermerkungen zum sogenannten Harnack-Prinzip. Mythos und Realität." In Die Kaiser-Wilhelm / Max Planck Gesellschaft und ihre Institute: Studien zu ihrer Geschichte, edited by Bernhard Vom Brocke and Hubert Laitko, 129-38. Berlin: de Gruyter.

Vom Brocke, Bernhard. 1990. "Die Kaiser-Wilhelm-Gesellschaft im Kaiserreich: Vorgeschichte, Gründung und Entwicklung bis zum Ausbruch des Ersten Weltkriegs." In Forschung im Spannungsfeld von Politik und Gesellschaft: Geschichte und Struktur der Kaiser-Wilhelm-/Max-Planck-Gesellschaft, edited by Rudolf Vierhaus and Bernhard Vom Brocke, 17-162. Stuttgart: Deutsche Verlags-Anstalt.

Vosko, Leah F. 2000. Temporary work: The gendered rise of a precarious employment relationship. Toronto: University of Toronto Press.

Warnier, Jean-Pierre. 2007. The pot-king: The body and technologies of power. Leiden: Brill.

White, Hylton. 2013. "In the shadow of time." Journal of the Royal Anthropological Institute 19 (2): 256-57. doi:10.1111/1467-9655.12030.

Zaloom, Caitlin. 2006. Out of the pits: Traders and technology from Chicago to London. Chicago: University of Chicago Press.

\section{Précarité académique que la dépendance hiérarchique dans la Société Max Planck}

Résumé : Cet essai examine les spécificités de la hiérarchie interne d’une des plus larges institutions de recherche en Allemagne, la Société Max Planck. Lessai déploie une analyse inspirée par Louis Dumont, ses concepts de valeur cardinale, d'englobement, et de complémentarité afin d'explorer la logique symbolique des relations au sein de cette structure. Par conséquent, l'article démontre que les valeurs cardinales d'autonomie et d'excellence de l'institution (incarnées par le comité des gouverneurs, englobant leurs départements respectifs) produisent la valeur complémentaire de dépendance des subalternes. Létude ethnographique auprès de trois scientifiques post-doctorat révèle que la dépendance est effectivement constituée comme un "mode d'action" (au sense de James Ferguson), dépendant de l'appui des directeurs. L'essai se termine en suggérant que l'omnipresence des contrats temporaires parmi ces acteurs n'est pas simplement-et comme beaucoup le pensentl'effet dune précarisation générale et néolibérale de la recherche. La précarité de l'emploi au sein de la société Max Planck est en fait l'expression contemporaine de dépendances initiées par une tradition plus ancienne de gestion du travail intellectuel et de la morphologie de la monarchie Allemande avant cela.

Vita PEACOCK is an ESRC Future Research Leaders Postdoctoral Research Fellow in the Department of Anthropology of University College London, where she 
is working on a book about the rise of "Anonymous" in Britain. This research is drawn from her doctoral thesis, "We, The Max Planck Society: A study of hierarchy in Germany."

Vita Peacock Department of Anthropology University College London 14 Taviton Street London WC1E 6BT $U K$ vita.peacock@ucl.ac.uk 